\title{
B111 循環溶媒を用いたプリント基板からの資源回収
}

Recovery of useful resources from print circuit board by liquefaction

伊藤 大禄 (千葉大) 正 中込 秀樹 (千葉大)
加茂 徹 (産総研)

Hiroyoshi ITOU and Hideki NAKAGOME, Chiba University, 1-33, Yayoicho, Inage-ku, Chiba-shi,

Chiba

Tohru KAMO, National Institute of Advanced Industrial Science and Technology (AIST), 16-1, Onogawa, Tsukuba-shi, Ibaraki

\begin{abstract}
Recovered and recycle useful metal from waste of electric and electronic equipment (WEEE) is necessary to secure a stable material supply. Fiber reinforced epoxy board was liquefied in biomass derived tar solvent. That was liquefied by using tar derived from Japanese cedar and benzyl alcohol or cresol mixture solvent also. Tar solvent was prepared from the liquid product by removing light fraction. Epoxy board was liquefied almost completely in the tar solvent from Japanese cedar and cresol mixture solvent at $300^{\circ} \mathrm{C}$ for $120 \mathrm{~min}$ under atmospheric pressure. Finally, most of solvent was recovered from thermal decomposition of the once liquefied epoxy board at $500-800^{\circ} \mathrm{C}$. These experimental results indicate that waste printed circuit board can be liquefied in a recyclable solvent that was derived from the once liquefied epoxy board.
\end{abstract}

Key Words: liquefaction, print circuit board, WEEE, recyclable solvent, biomass

\section{1.はじめに}

貴金属やレアアースは電子産業にとって必要不可欠であ り、これらの資源の長期的な安定供給を確保することは IT 産業を育成する上で重要である。使用済み電気電子機器 （WEEE）に貴金属やレアアースなどが多く含まれており、

有用資源の回収技術を開発することは重要である。

電子基板にはエポキシ樹脂やフェノール樹脂等の 3 次元 網目状構造を持つ熱硬化性樹脂が使われているため、単に 加熱しても分解することは困難である。超臨界流体や特殊 な溶媒を用いたプリント基板の可溶化法が提案されている (1), (2) が、高価な装置や溶媒を必要とするため実用化は困 難であった。本研究では廃木材などの安価なバイオマス由 来の溶媒を用いて常圧下でエポキシ樹脂を可溶化し、電子 基板から有用な資源を回収する方法を検討した。

\section{2. 実験方法・手順}

実験手順をFig.1 に示す。ガラス繊維強化エポキシ樹脂板 （日立化成社製）を杉の乾留タール、および杉粉をべンジ ルアルコールあるいはクレゾール混合溶媒中で液化して製 造した (タール1, タール2) 3 種の異なる溶媒を用いて可溶 化処理した。

乾留タールを用いた実験では、杉の背板を小型のベンチ スケールプラントを用いて $540^{\circ} \mathrm{C} て ゙ 5$ 時間熱分解して採取 したタールから沸点 $220^{\circ} \mathrm{C}$ 以下の軽質分を除去して溶媒を 製造し、エポキシ樹脂板を $220^{\circ} \mathrm{C} て ゙$ 可溶化処理した。

タール1は、杉粉に微量の水酸化ナトリウムを加えてべ ンジルアルコール中 $250 \sim 375^{\circ} \mathrm{C} て ゙$ 加熱処理して製造され、 この溶媒を用いてエポキシ樹脂板の可溶化を常圧下 $300^{\circ} \mathrm{C}$ 、 1 時間で行った。

タール 2 は、杉粉に微量の硫酸を添加してクレゾール混 合溶媒 (o-クレゾール、m-クレゾール、 $\mathrm{p}-$ クレゾールの混 合物）中フラスコを用いて $200^{\circ} \mathrm{C} 、 2$ 時間加熱処理し、 $250^{\circ} \mathrm{C}$ 以下の軽質留分を除去して製造した。エポキシ樹脂板の可 溶化は、タール 2 中 $200 \sim 300^{\circ} \mathrm{C} て ゙ 1 〜 2$ 時間行った。
エポキシ基板を可溶化した後、生成物をろ過して液体生 成物と残渣に分離し、残渣をテトラヒドロフランおよび蒸 留水で洗浄した後、 $110^{\circ} \mathrm{C} て ゙ 12$ 時間減圧乾燥させて重量を 測定した。可溶化率は（1）式を用いて算出した。

$$
\begin{aligned}
& \text { Liquefaction rate( } \%)=100-(c-b) /(a-b) \times 100 \\
& a: \text { weight of epoxy board } \\
& b: \text { weight of glass fiber in the sample } \\
& c: \text { weight of carbon residue }
\end{aligned}
$$

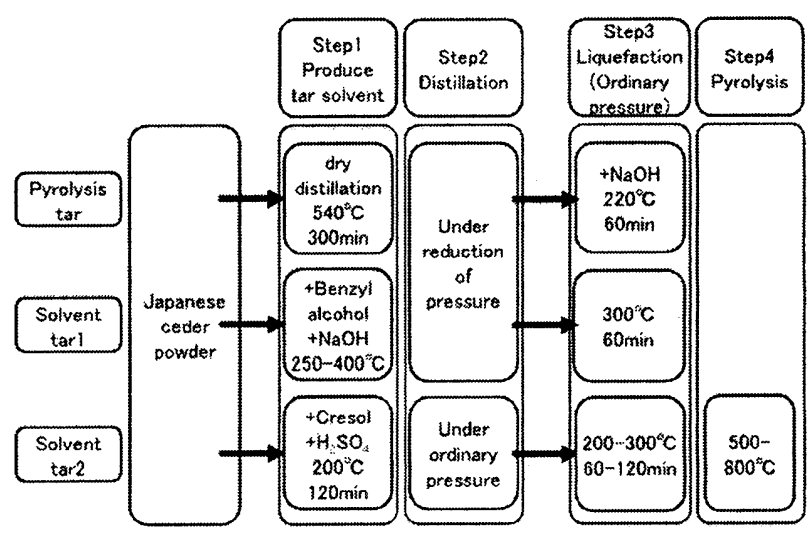

Fig. 1 Experimental procedure

\section{3. 結果と考察}

杉の乾留タールを用いてエポキシ樹脂板を可溶化させた 場合の可溶化率をFig.2 に示す。可溶化率は乾留タールの製 造条件によって異なるが 16 50\%であり、杉の乾留タール 中でエポキシ樹脂板が可溶化できることが分かった。 3 種 類の乾留タールをへキサンおよびテトラヒドロフランで抽 出すると、タールA はテトラヒドロフラン不溶分が少なく 軽質で、タールB およびタールC はへキサン可溶分が少な くテトラヒドロフラン不溶分が多く比較的重質であった。 


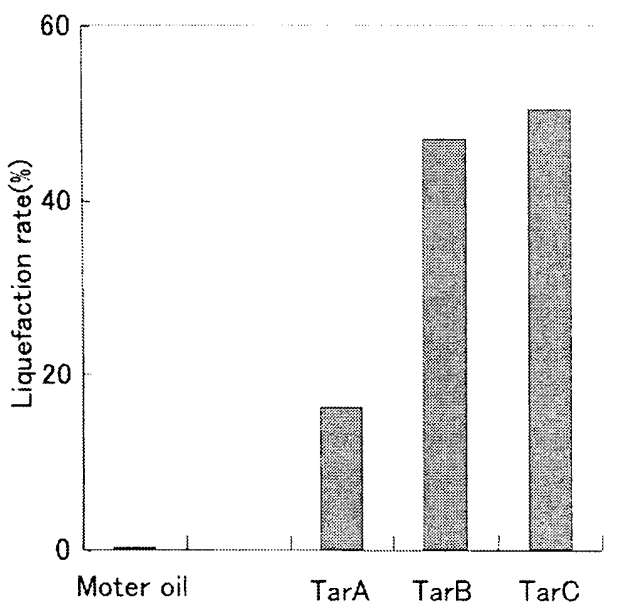

Fig.2 Liquefaction rate of epoxy board by three kinds of tar solvent

250〜 400ㄷで杉から製造したタール1を用いてエポキシ

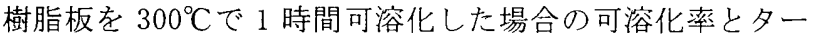
ルの製造温度との関係をFig.3に示す。タ一ルの製造温度が $250^{\circ} \mathrm{C}$ ではエポキシ樹脂はほとんど可溶化されないが、製造 温度が高くなるに従って急激に可溶化率は増加し、300 $\mathrm{C}$ で 可溶化率は約 $90 \%$ に達し、エポキシ樹脂板はほぼ完全に可 溶化された。タールの製造温度が $300^{\circ} \mathrm{C}$ より高くなると可 溶化率は急激に低下し、溶媒タールの性質は製造温度で敏 感に変化することが考えられる。

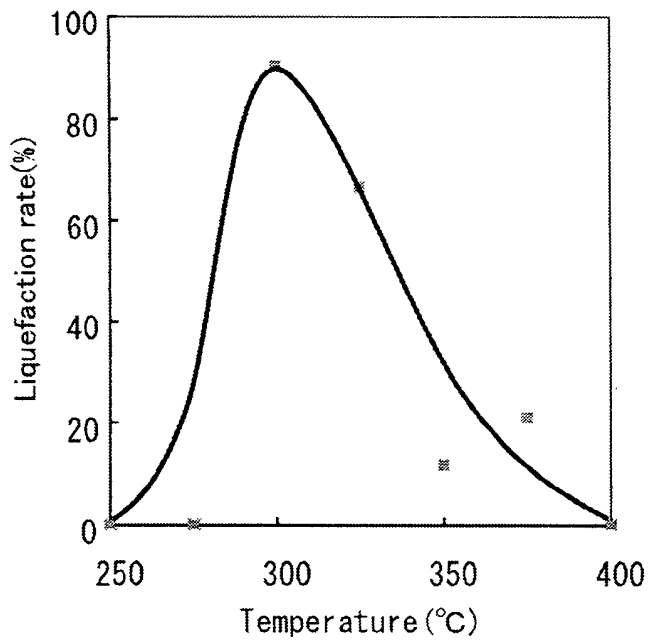

Fig. 3 Effect of treatment temperature of tar solvent on liquefaction rate

タール 2 を用いてエポキシ樹脂板を可溶化した場合の可 溶化率に対する可溶化処理温度の影響を Fig.4に示す。 $225^{\circ} \mathrm{C}$ 以下ではエポキシ樹脂板はほとんど可溶化されない が、 $250^{\circ} \mathrm{C}$ 以上では可溶化率は急激に增加して $80 \%$ 以上とな った。しかし、処理温度が $275^{\circ} \mathrm{C}$ 以上になると可溶化率は 若干減少した。可溶化率は 60 分以上可溶化時間を長くして もほぼ等しく、可溶化は比較的早い段階で終了しているこ とが明らかである。

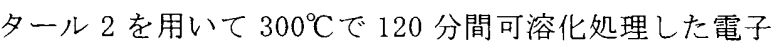
基板を Fig.5 に示す。エポキシ樹脂は可溶化処理によってほ ぼ完全に除去され、ガラス繊維や金メッキされた端子がそ のままの形を保ったまま回収された。

また、タール 2 中でエポキシ樹脂板を可溶化した後、可
溶化物を熱分解して得られた液体生成物にはフェノール、 クレゾールおよび各種のフェノール誘導体が多く含まれて おり、エポキシ樹脂板の溶媒として循環利用できることが 確認された。

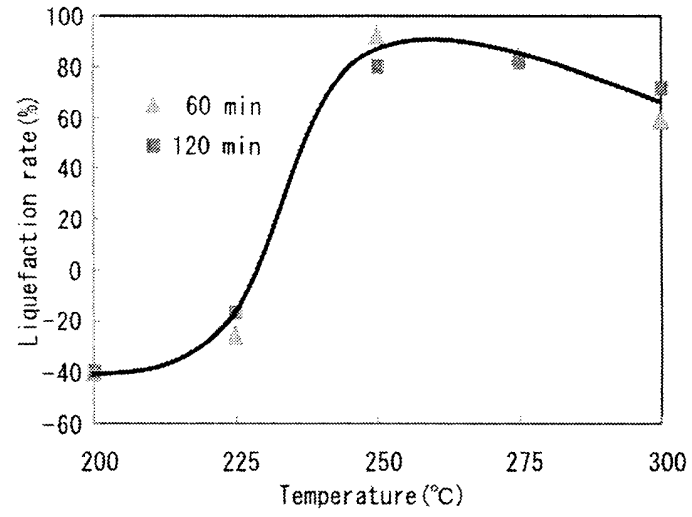

Fig.4 Effect of liquefied temperature on liquefaction rate

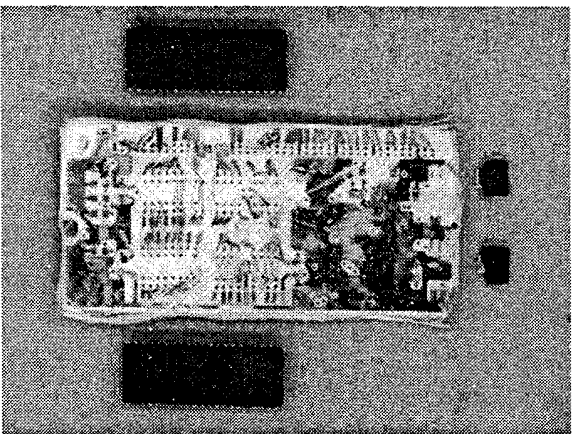

Fig. 5 Liquefied print curcuit board by solvent tar $2\left(300^{\circ} \mathrm{C}, 120 \mathrm{~min}\right)$

\section{4.まとめ}

杉を熱分解して得られる乾留タール、あるいは杉粉をべ ンジルアルコールまたはクレゾール混合溶媒中で処理して 得られるタールを用いるとエポキシ樹脂板は常圧下で可溶 化し、金属やガラス繊維を分離回収出来ることが分かった。 また一度可溶化されたエポキシ基板の熱分解生成物中には フェノール誘導体が多く含まれ、Fig.6のように溶媒を可溶 化物の熱分解生成物から製造し、再生溶媒として循環利用 出来ることが明らかにされた。

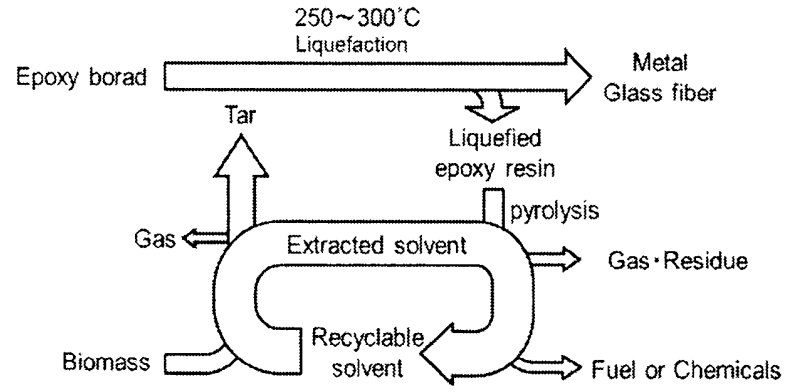

Fig.6 Liquefaction flow

\section{5. 参考文献}

(1) Y. Sato, Y. Kodera, and T. Kamo, Energy \& Fuels, 13, 364 (1999).

(2) K. Maekawa, K. Shibata, M. Iwai, A. Endo, Hitachi Chem. Technic. Rept., 42(1), 21 (2004). 